Lovorka Zergollern-Miletić

Faculty of Teacher Education

University of Zagreb

\title{
Croatian Students' Perception of American Culture
}

The article discusses the results of a study conducted among students of English at the Faculty of Teacher Education in Zagreb, Croatia. Although the study might be considered to be a rather limited one (60 participants), the author believes that it could give a general picture about the type of knowledge that young educated Croatians have about American culture. Generally speaking, the students-participants do not seem to be either positively or negatively biased regarding American culture. Their sources of information are mainly some aspects of formal education (school and/or university), complemented by TV and films. On the whole, the students do not think that they have good knowledge of American culture, and a number of them expressed the opinion that what they knew might only be stereotypes. This attitude may mean that at least some of the students - respondents will try to gain better insight into the subject of American culture in the future.

Key words: American culture, students, knowledge, stereotypes

\section{Culture - a short introduction}

'Culture' is a term that has several meanings. Anthropologists usually differentiate between Culture with a capital $\mathrm{C}$, and culture with a small c. Culture with a capital $\mathrm{C}$ is a generalized possession of the genus Homo, and includes a capacity and possession shared by hominids. The term 'culture' with a small c stands for the different and varied cultural traditions of specific societies (Kottak 37). Prominent American anthropologist Conrad Phillip Kottak explains that even anthropologists can get culture shock. Although anthropologists are scientists trying to combat ethnocentrism (the tendency to apply 
one's own cultural values in judging the behaviour and beliefs of people raised in other cultures), there are situations where even they cannot escape it. Ordinary people are more prone to suffer from various types of cultural shock. Therefore, there is a long tradition of books and guides explaining patterns of behaviour, mores and traditions of particular societies to individuals who are planning to visit, or even to start living in new, unfamiliar societies. On the other hand, there is ample literature based on cultural research, which was created with the aim of educating and consequently inspiring further research.

The field of studies called American Studies has been present for over half a century in the United States of America, as well as in different parts of the world. American culture has been a widely studied subject by scholars and students all around the globe. It suffices to enter 'American Studies' or 'American Culture' into any search engine on the Internet, and the user will immediately be provided with exhaustive reading lists and guidelines as how to obtain information about the subject matter. The introduction to the Oxford Bookworms Factfiles book on the USA suggests that for millions of people around the world the United States is one of the most interesting countries in the world. There are American things around us all the time (Baxter 2008). In spite of this, American culture is very often perceived in terms of preconceptions and stereotypes. ${ }^{1}$ This is not surprising, bearing in mind the fact that people often do not know much about their own culture, or tend to either idealize it or belittle it (Zergollern-Miletić 2001).

\section{American Culture and Croatia - some preliminary thoughts}

Croatians have a long history of relations with the United States. A large number of Croatians emigrated to the USA in the nineteenth century for economic reasons. In the twentieth century the reasons were either eco-

1 For an amusing yet instructive account of preconceptions and stereotypes about Americans that exist among the British, see Wesley Mead's article in The Ann Arbour Review of Books, October 4, 2012. 
nomic or political. We might say that Croatians had information about "The New World" long before the advent of modern media. For some, America was a land of promise, riches and amusement, while to others it represented the reason for their families' break up.

After WWII, when Croatia was part of socialist Yugoslavia (1945 1991), a person's outlook on the USA depended very much on their education, social status and political alignments.

This may also be true today. Nevertheless, I suggest that in today's Croatia people's opinion about the United States is mostly shaped by the media, primarily by popular culture.

Young Croatians are generally rather apolitical, so I do not consider that political decisions or military actions of the United States significantly shape their views.

\section{American Culture and Croatian Students - the study}

\section{The participants and the instrument}

In order to obtain information about young Croatians' perception of American culture, I conducted a study among students at the Faculty of Teacher Education in Zagreb, the capital of Croatia. As a university teacher, who has taught different language, translation and cultural courses to Croatian university students of English at different institutions, I have at times encountered unexpectedly deep-rooted prejudice in my students. Sometimes they even showed lack of willingness to accept new ideas and new perspectives on the cultures we were discussing, including their own (which in most cases was Croatian). Fortunately, this cannot be claimed for the majority of students. Another thing that can be noticed among Croatian students is that, in general, they are reluctant to think critically.

The present study included sixty participants - thirty second-year students and thirty third-year students at the Faculty of Teacher Education. Those students are training to be generalists, as well as primary school teachers of English. The study took place around the middle of the summer semes- 
ter, so the second-year students had not yet completed the course Cultures of the English-Speaking World. The instrument for the research was a questionnaire that contained seven open-ended questions, as follows:

- When you hear the term 'American Culture', what comes first to mind?

- Do you think you are familiar with American culture?

- What do you actually know about it?

- Where and how have you learned it?

- Have you ever been to the USA?

- Do you think that Croatians are, in general, familiar with American culture?

- Could you, please, compare American culture with Croatian culture?

It is important to report at the beginning that there is no difference in quality between the second- and third-year students' answers. Most of them reflect a careful approach to the matter. In other words, there were only a few students who did the task superficially, out of whom some did not even answer the last question. What should also be immediately said is that none of the students had ever been to the United States, and most of them had never been to any English-speaking country. About a third of them added to their answer in 5) that they would like to visit the States.

\section{Results and discussion}

Question 1) was supposed to provoke a quick, instant answer, an association, an emotional response, rather than a product of deep contemplation. Most students listed a few things they associated with America. The most frequent answer to that question was 'fast food' (12). The second-most frequent answer was 'Hollywood', 'films', 'movies', or 'Hollywood movies' (10). The third was history (9). One student even said 'their long history'. Several students mentioned 'numerous presidents'.

The fourth answer in terms of frequency was 'multiculturality', also ex- 
pressed as 'different nations' or'different peoples' (8).

The fifth answer was 'holidays' - such as Thanksgiving, 4th of July, etc. (8).

'A particular way of living' was the answer provided by seven students (with occasional additional comments such as 'houses in suburbs that look alike', 'a hectic way of life', 'big cities'). Universities was the first association recorded by six students, and various sports (primarily American football and baseball) by three.

There were two answers concerning American English or American accent. The same number of students mentioned 'opportunities', and yet another two mentioned Indians.

In two answers we can find 'hard-working people', and in one, 'numerous museums'.

Three students suggested, with some criticism implied, American efforts to promote their life-style and opinions to the rest of the world. These were the only respondents who expressed negative feelings in this part of the study.

The answers to question 2), whether the respondents think they are familiar with American culture, vary from 'no' to 'not enough' or 'so-so.' Only four students reported that they were familiar with it.

To question 3), what they actually know about American culture, the most frequent answer was: 'Something about their history' (15), where some students mentioned Indians, Puritans, or colonization. This answer is followed in frequency by the answer that the students had gained some general information (12). The third answer was about American holidays (10).

There were also answers about America being a consumer society, about it being a great world power, about the American lifestyle, where some students further explained that Americans move from place to place, and that they change careers much more often than, for instance, Croatians.

Some mentioned unhealthy or fast food as an answer to this question.

One student said: 'They don't learn about the rest of the world.'

On the other hand, two students suggested that their own knowledge 
about America might only include some stereotypes.

From the students' answers to question 3), we might conclude that most of the information they had gained had been provided by school or university courses, which will prove true in the students' answers to question 4).

As the answer to the question 'Where and how have you learned it?, most students mentioned school (15) and university (16), combined with TV (13), the internet (9) and movies (14). Newspaper articles, documentaries, National Geographic and History Channel did not appear often in the students' answers, but it is encouraging that they came up at all.

Some students had learned about America from the Americans they had met, or from friends or relatives who lived there.

The following question asked whether the respondents thought that Croatians are, in general, familiar with American culture. The prevalent answers to this question are 'no', 'not much', or 'they have wrong ideas about it, their ideas being shaped mostly by TV or films'.

Seven students said that Croatians were more familiar with American culture than the other way round. One said: 'Depends on your criteria, but I think they are all right.'

The final question required an analytical approach, a comparison between American culture and Croatian culture. The most frequent answer was that Americans are much more open-minded than Croatians, who are rather conservative. I find this answer rather intriguing. I would like to learn what these respondents meant by 'open-mindedness' and 'conservatism', so I am planning to conduct an interview with them in the course of the following academic year.

American multiculturalism was often mentioned in the respondents' answers, and I suppose that the fact that America is multicultural might be at least one of the reasons why a number of students consider Americans to be open-minded.

Several students think that both Americans and Croatians are traditional. From their answers we cannot see whether they see it as something positive or negative. The concept of 'traditionalism' in young Croatians' 
minds is yet another problem that I am considering to do research on.

Some students think that Americans and Croatians equally cherish their history and traditions, while others think that Croatians are the ones who take the lead here. On the other hand, there are students who think that Americans preserve their history and traditions, and Croatians ruin everything. We can see from these answers that the respondents consider tradition to be something positive.

Also present in a number of the students' answers is the idea that America is a modern, powerful country. Some students claim that Croatians try to imitate Americans.

According to a few, Americans are more hard-working. One student puts it like this: 'Croatians complain and dream. Americans work to acquire the American Dream.'

One student claims just the opposite, that Croatians are more hard-working.

Several students say that Americans do not have any knowledge about certain things that are considered general culture in Croatia, but Americans generally focus on their field of expertise, and they are good at it. One student puts it like this: 'Croatians have to know everything about everything' (referring to the Croatian system of education).

All students who mentioned food (4) agree that Croatians cook at home, and do not eat as much unhealthy food as Americans.

It is interesting to note that there are opposite views about the way of living, where some students consider the Croatian way to be more relaxed, and others just the other way round.

One student said that she had got the impression from films and sitcoms that there is more unity in American families. It would be interesting to analyse the role and the functioning of the American family as presented in modern American films and sitcoms, to see what information an average viewer might obtain. A superficial view on the American family, in comparison to the Croatian family, might give us just the opposite impression - that there is more unity within the Croatian family. Literature based on research 
might support that impression (Campbell and Kean 1997; Althen, Doran and Szmania 2003; Petak 2004; Bianchi, Robinson and Milkie 2006).

\section{Conclusion}

The present study is a rather limited one concerning the number of participants, yet I believe it can give some general picture about the type of knowledge that young educated Croatians have about American culture. We have seen that the students - participants in the study showed an awareness of the meaning of the term 'American culture'. They did not interpret it as arts or literature, but they understood that the term included history and traditions, as well as a way of living. Most students also showed some acquired knowledge of American culture, and the willingness to reflect on it.

In their answers to question 7) most of them tried to provide some analysis.

On the whole, these students do not seem to be either positively or negatively biased regarding American culture. On the other hand, a certain number of them showed great disapproval of Croatian culture. In my view, this disapproval reflects the present difficult political and economic situation in the country. In addition, I suppose students, like many other Croatians, are influenced by the media, which project a rather negative picture of Croatia.

The sources of information, as we can see from the students' responses, are mainly some kind of formal education (school and/or university), complemented by TV and films.

The students generally do not think that they have a good knowledge of American culture. Some of them even expressed the opinion that what they knew might only be stereotypes. This attitude may mean that at least some of the respondents will try to gain better insight into the subject of American culture in the future. Students training to be teachers should be encouraged to learn about their own culture - not just about various events from the past, but rather to try to approach it from various sides, and to develop a critical view of it. They should acquire an opinion that should not be easily shaped or swayed by the media. 
When future teachers of English are concerned, it is necessary that, in addition to their own culture, they learn as much as possible about the cultures of the English-speaking world. This does not imply merely learning about the kings and queens of England and being able to recite the presidents of the United States. In addition to learning about, to questioning and researching their own culture, English teachers should also develop a critical approach to the cultures of the English-speaking world.

Studies like the one whose results I have discussed in this article may be tiresome for the respondents. Nevertheless, such questionnaires can at least in a small way encourage them to reflect upon certain problems, and to question the truths (or "truths") that are presented to them.

\section{Works Cited}

Althen, G., Doran, A.R. and Szmania, S. J. American Ways. A Guide for Foreigners in the United States. Yarmouth, Maine: Intercultural Press, 2003.

Baxter, A. The USA. Oxford: Oxford UP, 2008.

Bianchi, S.M., Robinson, J.P. and Milkie, M.A. Changing Rhythms of American Family Life. New York: Russell Sage Foundation, 2006.

Campbell, N. \& Kean, A. American Cultural Studies: An Introduction to American Culture. London and New York: Routledge, 1997.

Kottak, C. P. Anthropology. The Exploration of Human Diversity. New York: McGraw-Hill, 1991.

Mead, W. "Imported Goods:British Perception of Americans and American Culture". The Ann Arbour Review of Books, October 4, 2012 <www.a2review.net/2012/.../ imported-goods-british-perception-american-culture $>$

Petak, A. “Obitelj u promjenama: rezultati istraživanja u Hrvatskoj”. Sociologija i prostor, 42. 1/2 (March 2009): 5-10.

Zergollern-Miletić, L. "Hrvatska kultura - kako se vidimo sami i kako nas vide drugi”. Drugi hrvatski slavistički kongres. Ed. Sesar, D. and Vidović Bold, I. Zagreb: Hrvatsko filološko društvo, 2001. 683-688. 